\title{
ENERGY KINGDOMS
}

CENTER ON GLOBAL ENERGY POLICY SERIES 


\section{CENTER ON GLOBAL ENERGY POLICY SERIES}

Jason Bordoff, series editor

Making smart energy policy choices requires approaching energy as a complex and multifaceted system in which decision makers must balance economic, security, and environmental priorities. Too often, the public debate is dominated by platitudes and polarization. Columbia University's Center on Global Energy Policy at SIPA seeks to enrich the quality of energy dialogue and policy by providing an independent and nonpartisan platform for timely analysis and recommendations to address today's most pressing energy challenges. The Center on Global Energy Policy Series extends that mission by offering readers accessible, policy-relevant books that have as their foundation the academic rigor of one of the world's great research universities.

Robert McNally, Crude Volatility: The History and the Future of Boom-Bust Oil Prices

Daniel Raimi, The Fracking Debate: The Risks, Benefits, and Uncertainties of the Shale Revolution

Richard Nephew, The Art of Sanctions: A View from the Field 


\section{ENERGY \\ KINGDOMS}

OIL AND POLITICAL

SURVIVAL IN THE

PERSIAN GULF

JIM KRANE

Columbia University Press

New York 


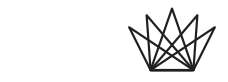

Columbia University Press

Publishers Since 1893

New York Chichester, West Sussex

cup.columbia.edu

Copyright (C) 2019 Columbia University Press

All rights reserved

Library of Congress Cataloging-in-Publication Data

Names: Krane, Jim, author.

Title: Energy kingdoms : oil and political survival in the Persian Gulf /

Jim Krane.

Other titles: Center on Global Energy Policy series.

Description: New York : Columbia University Press, 2019. | Series: Center on

Global Energy Policy series | Includes bibliographical references and index. Identifiers: LCCN 2018027640 | ISBN 9780231179300 (cloth : alk. paper) Subjects: LCSH: Petroleum industry and trade-Persian Gulf Region. |

Petroleum industry and trade-Political aspects-Persian Gulf Region. |

Energy consumption-Persian Gulf Region. | Energy policy-Persian

Gulf Region.

Classification: LCC HD9576.P52 K73 2019 | DDC 338.2/72809536-dc23

LC record available at https://lccn.loc.gov/2018027640

Columbia University Press books are printed on permanent and durable acid-free paper.

Printed in the United States of America

Cover image: (c) Hansmusa / Alamy Stock Photo 
FOR CONNIE

$\tilde{\ell}$ 
